\title{
Morphological evaluation of cork oak (Quercus suber): Mediterranean provenance variability in Tunisia
}

\author{
Mhemmed GANDOUR ${ }^{\mathrm{a} *}$, Mohamed Larbi KHOUJA ${ }^{\mathrm{b}}$, Lamjed TOUMI $^{\mathrm{c}}$, Saîda TRIKI $^{\mathrm{a}}$ \\ a Laboratoire de Biochimie, Département de Biologie, Faculté des Sciences de Tunis, Université Tunis El-Manar, Tunis 2092, Tunisia \\ ${ }^{\mathrm{b}}$ Laboratoire d'Écologie et d'amélioration Sylvo-Pastoral, Institut National des Recherches en Génie Rural Eau et Forêt (INRGREF), \\ BP 10 Ariana 2080, Tunisia \\ ${ }^{\mathrm{c}}$ Laboratoire de Génétique et Amélioration des Plantes, Institut Sylvo-Pastoral de Tabarka (ISPT), Tabarka 8110, Tunisia
}

(Received 4 April 2006; accepted 7 February 2007)

\begin{abstract}
Twenty-six provenances (2 340 plants) of cork oak (Quercus suber spp.) originating from Portugal, Spain, Italy, Morocco, Algeria, and Tunisia were tested for genetic variation among and within provenances by growth traits. Seven morphometrical characters were measured in 90 plants from each provenance. Analysis of variance showed highly significant differences for all characters. The phenotypic coefficient of differentiation reached 0.24 for the form and 0.22 for height, thus revealing a strong structuring between the provenances. Comparative study of growth among the provenances revealed more vigorous growth and better survival rate for those from Morocco, Spain, and Portugal, which may constitute better materials for afforestation. Furthermore, this variability appeared to be geographically structured and would be mainly genetically controlled, as cork oak provenances were cultivated under the same environmental conditions. Our results should be helpful for guide forest managers in afforestation.
\end{abstract}

Quercus suber / genetic variability / afforestation / Mediterranean plants

Résumé - Évaluation morphologique chez le chêne liège (Quercus suber) : variabilité des provenances méditerranéennes en Tunisie. La variabilité génétique inter et intra-provenances a été étudiée pour des caractères de croissance chez Quercus suber spp. 26 provenances ( 2340 individus) de chêne liège originaires d'Espagne, du Portugal, d'Italie, du Maroc, d'Algérie et de la Tunisie ont été implantées et testées. Sept caractères morphométriques, jugés discriminants, ont été mesurés chez 90 individus par provenance. L'analyse statistique des résultats a montré des différences hautement significatives entre ces provenances. Le plus haut coefficient de différentiation Qst est trouvé pour les caractères forme $(0,24 \%)$ et hauteur $(0,22 \%)$. L'étude comparative a en outre révélé une croissance plus vigoureuse associée à une moindre mortalité chez les provenances originaires du Portugal, d'Espagne et du Maroc, leur conférant ainsi un intérêt potentiel pour le reboisement. La variabilité observée chez le chêne liège apparaît structurée selon l'origine géographique et serait essentiellement de nature génétique, puisque toutes les provenances ont été cultivées dans les mêmes conditions pédoclimatiques.

Quercus suber / variabilité génétique / reforestation / plantes méditerranéennes

\section{INTRODUCTION}

The conservation of genetic diversity within species of economic importance is important in order to insure the potentialities of populations for future adaptation and future breeding programs $[8,21,39]$. Information on genetic variation within and between populations, and about existing adaptability, can therefore be valuable both in prioritizing populations for conservation, and for developing sustainable management practices $[20,40,44]$. Characteristics such as high levels of phenotypic plasticity $[14,15,42]$ and genetic variation contribute to the success of the genus Quercus [11,13,17,24,32,34,45]. Studies on European white oaks (subgenus Quercus) showed that most genetic variation was found within populations rather than between populations or between species. It was reported that $74 \%$ of isoenzyme diversity was found within populations, whereas inter-populations and inter-species variations were $3 \%$ and $23 \%$ respectively [17]. Exceptionally,

*Corresponding author: gandourmed@yahoo.fr the allozyme diversity between populations of Quercus suber (11\%) was relatively high when compared to other oak species [41].

General interest comes mainly from the need to preserve genetic resources and to use them in rehabilitation programs. Nevertheless, few information regarding the performance and adaptation traits of Quercus suber are available. In order to limit the progressive reduction of cork oak distribution areas, a multi-locality provenance trial was established in 1997 at the site of Tebaba mountain (Tunisia), as a part of EUFORGEN Network. It is worth mentioning that the study of morphological differentiation among populations is a first step for the estimation of the evolutionary forces promoting or preventing differentiation. Population differentiation may be promoted by either natural selection or genetic drift. Intense natural selection may favor different phenotypes in each population in response to differences in selective regimes among localities.

In the present study we aim to: (1) examine the level of genetic variation among 26 local and introduced provenances 
Table I. Geographical, edaphic and climatic characteristic for the sample populations of cork oak (Quercus suber L.) [10].

\begin{tabular}{|c|c|c|c|c|c|c|}
\hline Code & Country & Locality & Altitude (m) & $\mathrm{P}(\mathrm{mm})$ & Substrate & Latitude \\
\hline$\overline{\mathrm{DZ}} 1$ & Algeria & Guerbes & - & - & - & - \\
\hline ES-PT 2 & Portugal-Spain & Basteros+ Sierra de San Pedro Tojera1 & $450-515$ & 778 & Siliceous & $39^{\circ} 12^{\prime} \mathrm{N}$ \\
\hline TN 3 & Tunisia & B. Fernana & 270 & 1610 & Siliceous & $36^{\circ} 35^{\prime} \mathrm{N}$ \\
\hline $\mathrm{TN} 4$ & Tunisia & Makna & 12 & 948 & Siliceous & $36^{\circ} 57^{\prime} \mathrm{N}$ \\
\hline IT 5 & Italia & Lazio Tuscania & 160 & 937 & Eruptive & $42^{\circ} 25^{\prime} \mathrm{N}$ \\
\hline IT 6 & Italia & Puglia Prindizi & 45 & 588 & Clayey & $40^{\circ} 34^{\prime} \mathrm{N}$ \\
\hline IT 7 & Italia & Sicilia Catania & 250 & 448 & Terra rosa & $37^{\circ} 07^{\prime} \mathrm{N}$ \\
\hline IT 8 & Italia & Sardaigna Cagliari & 200 & 883 & Granite & $40^{\circ} 27^{\prime} \mathrm{N}$ \\
\hline IT 9 & Italia & Sardaigna Sassari & 300 & 910 & Eruptive & $39^{\circ} 05^{\prime} \mathrm{N}$ \\
\hline MA10 & Morocco & Bousafi & 150 & 574 & Clayey & $35^{\circ} 11^{\prime} \mathrm{N}$ \\
\hline MA11 & Morocco & Ain Rami & 300 & 1280 & Siliceous & $35^{\circ} 07^{\prime} \mathrm{N}$ \\
\hline MA12 & Morocco & Canton d'Ain Johra & 150 & 479 & Clayey & $34^{\circ} 07^{\prime} \mathrm{N}$ \\
\hline MA13 & Morocco & Oulmes Piles 65 & 1115 & 673 & Schistose & $33^{\circ} 46^{\prime} \mathrm{N}$ \\
\hline MA14 & Morocco & Bab Azhar pile202 & 1130 & 970 & Schistose & $34^{\circ} 12^{\prime} \mathrm{N}$ \\
\hline ES15 & Spain & Montes de Toledo Ca Amero (V) & $600-800$ & 1063 & Siliceous & $39^{\circ} 22^{\prime} \mathrm{N}-39^{\circ} 25^{\prime} \mathrm{N}$ \\
\hline ES16 & Spain & Morena oriental Fuencaliente (CR) & $700-900$ & 719 & Siliceous & $38^{\circ} 24^{\prime} \mathrm{N}-38^{\circ} 33^{\prime} \mathrm{N}$ \\
\hline ES17 & Spain & $\begin{array}{c}\text { Sierra Morena Occidental Jerez de Los } \\
\text { Caballeros }\end{array}$ & $400-500$ & 666 & Siliceous & $38^{\circ} 13^{\prime} \mathrm{N}$ \\
\hline ES18 & Spain & $\begin{array}{c}\text { Parque de Los Alcarnocales la } \\
\text { Almorema (ALM) }\end{array}$ & $20-120$ & 993 & Siliceous & $36^{\circ} 16^{\prime} \mathrm{N}$ \\
\hline ES19 & Spain & $\begin{array}{l}\text { Catalu a Littoral Santa } \\
\text { Colomba de Farmes } 66\end{array}$ & $200-500$ & 802 & Siliceous & $41^{\circ} 51^{\prime} \mathrm{N}-41^{\circ} 53^{\prime} \mathrm{N}$ \\
\hline $\mathrm{ES} 20$ & Spain & Sierra Gouadarrama el Pardo (PAR) & $680-740$ & 455 & Siliceous & $40^{\circ} 31^{\prime} \mathrm{N}$ \\
\hline ES21 & Spain & J. Alpujarras Haza de lino-H & 1300 & 742 & Schistose & $36^{\circ} 50^{\prime} \mathrm{N}$ \\
\hline PT22 & Portugal & Chamusca & 75 & 829 & Schistose & $36^{\circ} 35^{\prime} \mathrm{N}$ \\
\hline PT23 & Portugal & Ponte de Sor & 70 & 710 & Siliceous & $36^{\circ} 35^{\prime} \mathrm{N}$ \\
\hline PT24 & Portugal & Sain Bras Alportel & $440-485$ & 874 & Siliceous & $36^{\circ} 35^{\prime} \mathrm{N}$ \\
\hline PT25 & Portugal & Evorra Azurrija & 360 & 564 & Siliceous & $36^{\circ} 35^{\prime} \mathrm{N}$ \\
\hline PT26 & Portugal & Saintiago de Cacem & 140 & 736 & Siliceous & $36^{\circ} 35^{\prime} \mathrm{N}$ \\
\hline
\end{tabular}

P: average annual rainfall.

of Quercus suber, (2) examine the pattern of genetic variation among these populations and (3) estimate some genetic parameters for each of the studied characteristic.

\section{MATERIALS AND METHODS}

\subsection{Plant material and sampling method}

Twenty-six provenances of cork oak were sampled from six countries (Tab. I). The latter were evaluated in the INRGREF station in the region of Nefza (140 km to the west of Tunis), where 30 blocks were defined. The pre-planting started in 1997. Cork oak seedlings were grown for 4 months in monospecific conditions without fertilizer in order to eliminate any source of variation. Then, they were planted in 30 randomized complete blocks at Nefza station. Each block contained 3 rows, so that 78 trees of the 26 provenances were planted as follows: 1 tree of each provenance per row, at $3 \times 2 \mathrm{~m}$ spacing. No treatment had been undertaken until the date of sampling.

\subsection{Desciption of the site}

The experimental site of Nefza is one of the several plantations of varied Quercus suber provenances, which have been set up by INRGREF in northern Tunisia. This plantation is located in the southern side of Tebaba mountain ( $8^{\circ} 52^{\prime} \mathrm{E}, 36^{\circ} 58^{\prime} \mathrm{N}$ ), zone corresponding to the numidian flysh, that extends from Oligocene to early Miocene $[3,4,29]$, on clay and sandstone flysh soils. The site is located at an altitude of $250 \mathrm{~m}$ under a humid bioclimate. Before planting, the dominant species were Quercus suber, Pistacia lentiscus L., Olea europaea L., Calycotome spinosa L., Cistus monspeliensis L., Inula viscosa, Phyllerea angustifolia, Lavandula stoechas, and Erica arborea.

\subsection{Morphological characters}

At the study site, seven response variables were measured on each surviving tree in each block: total tree height (HT), diameter at base (DB), crown width at two perpendicular directions, form (on a subjective scale from 1 (poor quality) to 3 (good quality), according to straightness and verticality), vigour (on a subjective scale from 1 (poor state) to 3 (good state)) [1], and the survival percentage (SUR) for each provenance per block.

\subsection{Statistical analyses}

Prior to statistical analysis, the percentages of survival rate were transformed with angular (arcsin) transformation. Variation among provenances in adaptive traits was analyzed using both univariate 
Table II. Descriptive statistics of characters measured in 26 provenances within 7 populations of Quercus suber (Means, coefficients of variation $(\%), F$ statistic for characters which gave a significant result using ANOVA and Level of population differentiation in quantitative characters as determined by $Q_{s t}$ and its $95 \%$ lower confidence limit $(C L)$ ). Standard errors (SE) of $Q_{s t}$ are in parentheses.

\begin{tabular}{|c|c|c|c|c|c|c|c|c|c|c|}
\hline \multirow[b]{2}{*}{$\mathrm{N}$} & \multirow[b]{2}{*}{ Variable } & \multirow[b]{2}{*}{ Average } & \multicolumn{3}{|c|}{ Provenances } & \multicolumn{3}{|c|}{ Populations } & \multirow[t]{2}{*}{ Qst (SE) } & \multirow[t]{2}{*}{$\mathrm{CL}$} \\
\hline & & & $\mathrm{F}$ & C.V.\% & Df & $\mathrm{F}$ & C.V.\% & Df & & \\
\hline 1 & Total tree height & $45.07(\mathrm{~cm})$ & $4.90 * *$ & 59.13 & 25 & $11.8^{* *}$ & 59.13 & 6 & $0.22(0.18)$ & -0.076 \\
\hline 2 & Diameter at base & $2.036(\mathrm{~cm})$ & $1.62 *$ & 68.3 & 25 & $2.61 * *$ & 68.3 & 6 & $0.13(0.09)$ & -0.018 \\
\hline 3 & Crown width1 & $52.44(\mathrm{~cm})$ & $2.84 * *$ & 58.86 & 25 & $4.07 * *$ & 58.8 & 6 & $0.148(0.16)$ & -0.11 \\
\hline 4 & Crown width2 & $71.51(\mathrm{~cm})$ & $2.10 * *$ & 51.09 & 25 & $2.09 * *$ & 51.09 & 6 & $0.143(0.13)$ & -0.07 \\
\hline 5 & Vigour & 2.07 (score) & $2.51 * *$ & 40.57 & 25 & $4.61 * *$ & 40.57 & 6 & $0.18(0.105)$ & 0.007 \\
\hline 6 & Form & 2.14 (score) & $3.83 * *$ & 36.44 & 25 & $10.45^{* *}$ & 36.44 & 6 & $0.247(0.145)$ & 0.008 \\
\hline 7 & Survival & 11.18 (score) & $1.50 *$ & 43.8 & 25 & $2.77 *$ & 43.8 & 6 & $0.18(0.129)$ & -0.032 \\
\hline
\end{tabular}

** F significant at $0.1 \%$. $C L=Q_{s t}-(1645 \times S E)$.

Table III. Descriptive statistics (mean, standard deviation and rank) for each morphological trait measured in 26 provenances of Quercus suber. Homogenous groups at $95 \%$ confidence (SNK) are presented by the same letter for each trait.

\begin{tabular}{|c|c|c|c|c|c|c|c|}
\hline & Total tree height & Diameter at base & Crown width1 & Crown width2 & Vigour & Form & Survival \\
\hline Prov & mean, (SD), SNK & mean, (SD), SNK & mean, (SD), SNK & mean, (SD), SNK & mean, (SD), SNK & mean, (SD), SNK & mean, (SD), SNK \\
\hline 1 & $44.04(25.82)$ af & $1.76(0.95) \mathrm{ab}$ & $47.12(27.76) \mathrm{ac}$ & $65.38(35.71) \mathrm{ac}$ & $1.98(0.80) \mathrm{ab}$ & $2.21(0.80) \mathrm{ae}$ & $1.05(0.58) \mathrm{ab}$ \\
\hline 2 & 44.41 (27.57) af & $2.06(1.22) \mathrm{ac}$ & $49.31(29.22) \mathrm{ac}$ & $68.26(34.37) \mathrm{ac}$ & $2.08(0.82) a b$ & $2.30(0.73)$ be & $1.45(0.29) \mathrm{b}$ \\
\hline 3 & $37.34(19.28) \mathrm{ad}$ & $1.79(1.00) \mathrm{ab}$ & $46.70(27.30) \mathrm{ac}$ & $66.54(33.06) \mathrm{ac}$ & $1.89(0.81) \mathrm{ab}$ & $1.92(0.80) \mathrm{ac}$ & $0.96(0.58) \mathrm{a}$ \\
\hline 4 & $47.44(24.85) \mathrm{bf}$ & $2.08(1.03) \mathrm{ac}$ & $60.15(31.52) b c$ & $77.28(35.74) \mathrm{ac}$ & $2.10(0.82) \mathrm{ab}$ & $2.05(0.79) \mathrm{ad}$ & $1.14(0.55) \mathrm{ab}$ \\
\hline 5 & $37.51(19.88) \mathrm{ad}$ & $1.88(0.78) \mathrm{ac}$ & 46.10 (29.79) ab & $64.16(33.94) \mathrm{ac}$ & $1.79(0.81) \mathrm{a}$ & $1.94(0.77) \mathrm{ac}$ & $1.25(0.51) \mathrm{ab}$ \\
\hline 6 & $35.00(22.16) \mathrm{ab}$ & $1.91(1.18) \mathrm{ac}$ & $51.16(31.49) \mathrm{ac}$ & $69.40(36.85) \mathrm{ac}$ & $1.86(0.90) a b$ & $1.86(0.74) a b$ & $0.95(0.55) \mathrm{a}$ \\
\hline 7 & $36.79(17.63) \mathrm{ac}$ & $1.97(1.04) \mathrm{ac}$ & $51.44(31.96) \mathrm{ac}$ & $72.17(36.36) \mathrm{ac}$ & $1.82(0.84) \mathrm{a}$ & $1.80(0.83) \mathrm{a}$ & $0.99(0.51) \mathrm{ab}$ \\
\hline 8 & $31.74(15.72) \mathrm{a}$ & $1.69(0.83) \mathrm{a}$ & $40.41(23.92) \mathrm{a}$ & 59.13 (31.90) ab & $1.86(0.84) a b$ & $2.04(0.76) \mathrm{ad}$ & $1.12(0.46) \mathrm{ab}$ \\
\hline 9 & $40.78(21.32) \mathrm{ae}$ & $2.02(1.11) \mathrm{ac}$ & $49.86(30.35) \mathrm{ac}$ & $71.04(38.66) \mathrm{ac}$ & $2.16(0.79) \mathrm{ab}$ & $2.10(0.78) \mathrm{ae}$ & $1.14(0.55) \mathrm{ab}$ \\
\hline 10 & 52.50 (24.18) ef & $2.19(1.10) \mathrm{ac}$ & $62.96(35.47) \mathrm{c}$ & $81.58(38.49) \mathrm{c}$ & $2.09(0.81) \mathrm{ab}$ & $2.22(0.77) \mathrm{ae}$ & $0.92(0.65) \mathrm{a}$ \\
\hline 11 & 52.76 (29.59) ef & $2.04(1.18) \mathrm{ac}$ & $61.31(32.61) b c$ & $78.24(35.63) b c$ & $2.06(0.85) a b$ & $2.34(0.76) \mathrm{ce}$ & $1.32(0.42) \mathrm{ab}$ \\
\hline 12 & $49.77(25.80) \mathrm{cf}$ & $1.93(0.95) \mathrm{ac}$ & $51.74(28.78) \mathrm{ac}$ & 70.80 (37.39) ac & $2.25(0.77) \mathrm{ab}$ & $2.47(0.75) \mathrm{de}$ & $1.08(0.56) \mathrm{ab}$ \\
\hline 13 & $57.13(31.42) \mathrm{f}$ & $2.30(1.16) \mathrm{bc}$ & $59.54(32.15) \mathrm{bc}$ & $79.60(34.82) \mathrm{c}$ & $2.13(0.82) a b$ & $2.52(0.60) \mathrm{e}$ & $1.17(0.55) \mathrm{ab}$ \\
\hline 14 & $49.47(32.26) \mathrm{cf}$ & $2.14(1.30) \mathrm{ac}$ & 50.85 (33.74) ac & $69.70(41.02) \mathrm{ac}$ & $2.09(0.86) \mathrm{ab}$ & $2.27(0.78)$ be & $1.17(0.56) \mathrm{ab}$ \\
\hline 15 & 47.14 (32.96) bf & $2.16(1.18) \mathrm{ac}$ & $54.37(33.04) \mathrm{ac}$ & $74.80(41.56) \mathrm{ac}$ & $2.11(0.82) a b$ & $2.21(0.81) \mathrm{ae}$ & $1.24(0.48) \mathrm{ab}$ \\
\hline 16 & 42.84 (22.49) ae & $2.00(0.93) \mathrm{ac}$ & $50.42(29.82) \mathrm{ac}$ & $67.52(34.75) \mathrm{ac}$ & $2.22(0.79) a b$ & $2.30(0.70)$ be & $1.08(0.52) \mathrm{ab}$ \\
\hline 17 & 46.33 (24.74) bf & $2.58(4.63) \mathrm{ac}$ & $57.02(32.83) b c$ & $75.34(35.85) \mathrm{ac}$ & $2.20(0.86) a b$ & $2.12(0.78) \mathrm{ae}$ & $1.19(0.53) \mathrm{ab}$ \\
\hline 18 & 52.61 (31.16) ef & $2.40(1.12) \mathrm{c}$ & $56.90(29.03) b c$ & $78.82(35.70) \mathrm{c}$ & $2.19(0.81) a b$ & $2.26(0.77)$ be & $1.20(0.55) \mathrm{ab}$ \\
\hline 19 & $52.19(30.03)$ ef & $2.19(1.12) \mathrm{ac}$ & $55.50(33.37) \mathrm{ac}$ & $75.19(43.58) \mathrm{ac}$ & $2.33(0.86) b$ & $2.16(0.79) \mathrm{ae}$ & $1.07(0.57) \mathrm{ab}$ \\
\hline 20 & 37.15 (19.43) ad & $1.83(1.06) \mathrm{ac}$ & $45.46(28.41) \mathrm{ab}$ & $64.16(34.95) \mathrm{ac}$ & $2.08(0.89) \mathrm{ab}$ & $1.94(0.76) \mathrm{ac}$ & $1.27(0.48) a b$ \\
\hline 21 & $40.41(24.86) \mathrm{ae}$ & $1.88(0.97) \mathrm{ac}$ & $39.82(22.59) \mathrm{a}$ & $58.44(29.57) \mathrm{a}$ & $2.16(0.87) \mathrm{ab}$ & $2.06(0.79) \mathrm{ad}$ & $1.19(0.53) \mathrm{ab}$ \\
\hline 22 & $46.42(27.38) \mathrm{bf}$ & $2.26(1.26) \mathrm{ac}$ & 54.68 (28.64) ac & $75.05(34.56) \mathrm{ac}$ & $2.26(0.82) a b$ & $2.08(0.81) \mathrm{ad}$ & $1.16(0.49) \mathrm{ab}$ \\
\hline 23 & $51.00(31.57) \mathrm{df}$ & $2.18(1.11) \mathrm{ac}$ & $56.59(33.06) b c$ & $76.02(37.22) \mathrm{ac}$ & $2.16(0.83) \mathrm{ab}$ & $2.13(0.76) \mathrm{ae}$ & $1.25(0.41) \mathrm{ab}$ \\
\hline 24 & 42.79 (26.19) ae & $1.84(0.97) \mathrm{ac}$ & $51.26(29.60) \mathrm{ac}$ & 70.97 (34.89) ac & $1.80(0.83) \mathrm{a}$ & $2.00(0.80) \mathrm{ac}$ & $1.08(0.52) \mathrm{ab}$ \\
\hline 25 & 40.63 (21.32) ef & $2.00(0.97) \mathrm{ac}$ & 54.36 (32.93) ac & 74.77 (39.65) ac & $1.96(0.82) \mathrm{ab}$ & $2.03(0.70) \mathrm{ad}$ & $1.26(0.44) \mathrm{ab}$ \\
\hline 26 & $53.58(31.75)$ ef & $2.17(1.24) \mathrm{ac}$ & $58.03(29.96) \mathrm{ab}$ & $77.32(34.82) \mathrm{ac}$ & $2.24(0.82) \mathrm{ab}$ & $2.25(0.72)$ be & $1.26(0.44) \mathrm{ab}$ \\
\hline
\end{tabular}


and multivariate methods. A two-way ANOVA was conducted for all traits including population and provenance effect using the following model: $Y_{i j k}=\mu+P_{i}+B_{i j}+E_{i j k}$.

Where $Y_{i j k}$ : the phenotypic value of the trait $Y$ in the $K$ th plant of the jth provenance in the ith population, $\mu$ : overall mean, $P_{i}$ : population effect, $B_{i j}$ : the effect of provenance $j$ in population $i$, and $E_{i j k}$ : error term specified by the effect of plant $\mathrm{k}$ of the provenance $j$ from population $i$. The variability of the morphological characters among provenances was measured by calculating the coefficient of variation $(C V)$ [37]. The levels of genetic variance within $\left(V_{G}\right)$ and between populations $\left(V_{B}\right)$ were evaluated using ANOVA. Estimated $V_{B}$ and $V_{G}$ were used to quantify the level of population differentiation $\left(Q_{s t}\right)$ for each trait $[27,28,38]: Q s t=\frac{V_{B}}{V_{B}+2 V_{G}}$. This parameter is analogous to Weir and Coockerham parameter (Fst) (1984) [43] and therefore provides an opportunity to compare population divergence in phenotypic characters and allozyme markers. This calculation assumes that the differences between populations are genetically controlled. This assumption is plausible when plants are grown in the same environment; it is the case of this study. Product moment and Spearman's correlations between each trait and the origin site characteristics were calculated following appropriate procedures [35]. It is worth noting that Spearman's rank correlation is the best-known procedure for studying the degree of relationship between 2 variables when there is sub-normality in both pairs of variables. Geographic differentiation among provenances in growth traits was explored by means of cluster analysis using an unweighted pair-group method with arithmetic averaging (UPGMA; [36]), and Euclidian distances as the criterion for clustering (STATISTICA for windows version 3.10). Finally, in order to test the correlation between genetic and geographical distances among populations, a Mantel test [25] was performed using the program GENETIX (version 4.02). The null hypothesis refers to absence of association between the elements of the pairs of matrices. The matrix of geographical distances was calculated by converting geographical coordinates to Cartesian coordinates $(x, y$ and $z)$ and the Euclidian distance (dab) between two points ( $a$ and $b$ ) was calculated as follow:

$$
\mathrm{dab}=\sqrt{(x a-x b)^{2}+(y a-y b)^{2}+(z a-z b)^{2}} .
$$

\section{RESULTS}

Growth traits analyzed between provenances (total tree height, diameter at base, crown width at two perpendicular directions, form, vigour and the survival percentage) showed coefficients of variation (C.V.), ranging from $36 \%$ for the form to $59 \%$ for total tree height (Tab. II). The most variable characters, total height and crown width1, were 1.6-fold more variable than form trait, characterized by the lowest coefficients of variation (Tab. II). In spite of the observed moderate variation, the two-way ANOVA revealed statistically significant differences in mean and score values among provenances for each examined trait (Tab. II). Similarly, on the population basis, coefficients of variation ranged from $36 \%$ to $59 \%$ (Tab. II).

Mean traits and provenances ranking are shown in Table III. In the whole, Moroccan provenance (Oulmes: 13) was exceptionally excellent in regard to height and stem straightness. Spanish provenance (la Almorema: 18) had a thick diameter and a regular crown width and form. Furthermore, total height was the most discriminate variable between populations.
Table IV. Spearman's coefficient correlation $(r)$ between measured traits and geographic parameters of origin site.

\begin{tabular}{lccccc}
\hline Variable & $\mathrm{T}$ & $\mathrm{P}$ & Altitude & Longitude & Latitude \\
\hline Total tree height & $-0.57^{* *}$ & 0.18 & 0.07 & $0.63^{* * *}$ & $-0.5^{* *}$ \\
Diameter at base & -0.30 & 0.14 & 0.03 & $0.46^{* *}$ & -0.28 \\
Crown width1 & $-0.40^{* *}$ & 0.20 & -0.22 & 0.36 & $-0.39^{* *}$ \\
Crown width2 & -0.36 & 0.16 & -0.25 & 0.36 & -0.39 \\
Vigour & -0.27 & 0.01 & 0.18 & $0.56^{* *}$ & -0.16 \\
Form & $-0.64^{* * *}$ & 0.06 & 0.34 & $0.56^{* *}$ & $-0.54^{* *}$ \\
Survival & -0.04 & 0.21 & 0.23 & $0.47^{* *}$ & 0.15 \\
\hline
\end{tabular}

* Significant at the $5 \%$ level. ${ }^{* *}$ Significant at the $1 \%$ level. $* * *$ Significant at the $0.1 \%$ level.

Except the survival-remaining traits, where no correlation was found, all the morphological characters were positively correlated, and correlation coefficients among all characters were statistically significant. On the other hand, a negative correlation was observed between characteristics of the origin sites (temperature and latitude) and growth traits in 6 yearold Quercus suber trees. Seedlings especially originating from high temperature sites displayed the lowest growth traits in this experimental site characterized by a low altitude $(250 \mathrm{~m})$. The highest correlations were found between height-longitude, height-temperature, and form-temperature of the origin sites $(0.63,-0.57$, and -0.64 respectively) (Tab. IV).

Survival rate showed a significant difference among provenances $(P=0.01)$. It varied from $95 \%$ for Spain-Portugal provenance (No. 2) to $70 \%$ for the Morocco one (No. 10). Estimates of $Q_{s t}$ differed widely between traits (Tab. II). $Q_{s t}$ values, as well as the mean estimate over traits, differed significantly from zero. They ranged from 0.137 to 0.31 . The greatest $Q_{s t}$ is found for form $(0.24, P<0.001)$ and height $(0.22, P<0.001)$. Survival and vigour $(0.18, P<0.001)$, exhibited also significant differences among population, although at a reduced level. Diameter, crown width1 and crown width2 displayed the least population differentiation $(0.137,0.148$, and 0.143 respectively) although values were significantly greater than zero.

In order to examine if the differentiation is a consequence of genetic drift and/or of natural selection, we have performed a cluster analysis (UPGMA), which groups the provenances on the basis of traits similarities. Two groups were revealed: The first group was constituted by the provenances originating from Morocco, Spain, and Portugal, while the second included those from Italy, Algeria and Tunisia (Fig. 1). A high correlation was found between genetic distances and geographic distances ( $r=0.699 ; P=0.039$ ) based on the Mantel test. The one-tail probability indicated that the null hypothesis could be rejected, suggesting a clear geographical pattern of isolationby-distance in the distribution of the species genetic variability. 


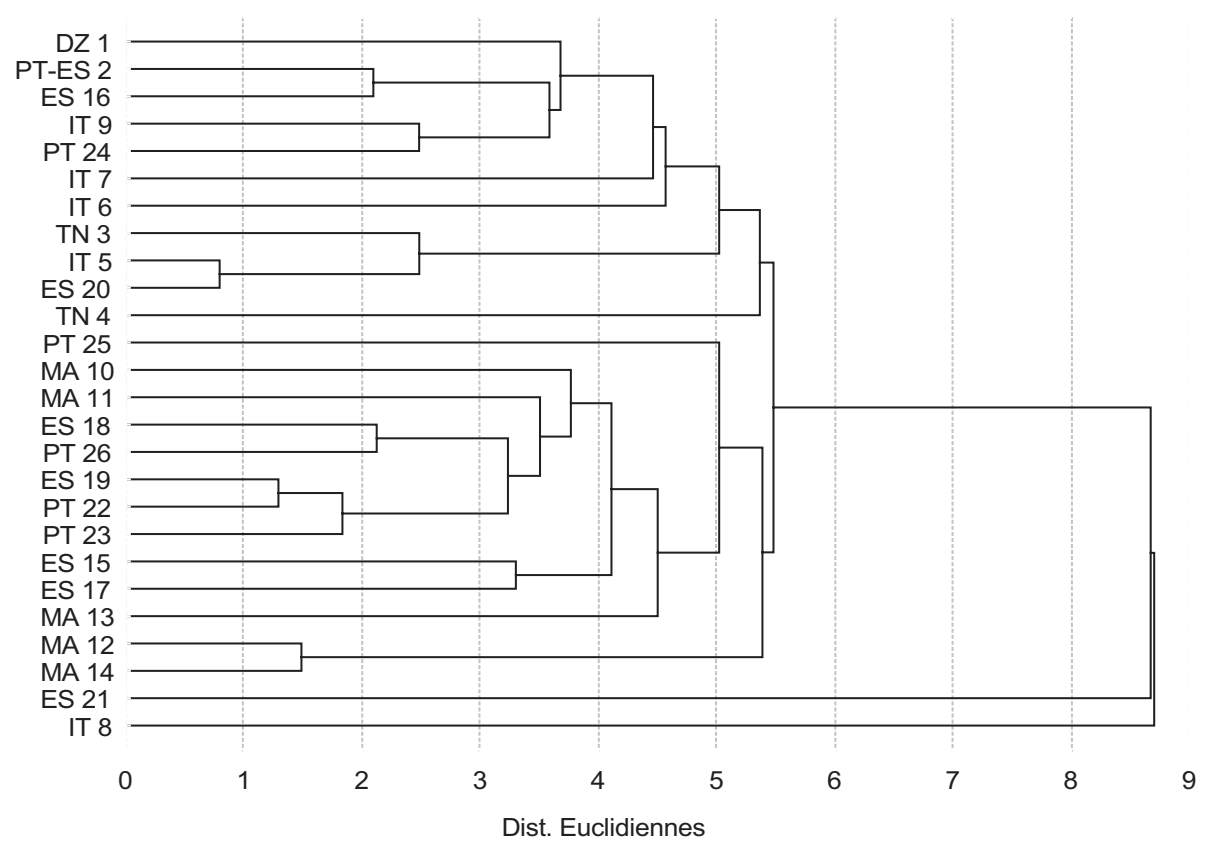

Figure 1. Spearman's coefficient correlation (r) between measured traits and geographic parameters of origin site. ( $\mathrm{T}^{\circ}$, $\mathrm{P}$, Altitude, Longitude, and Latitude).

\section{DISCUSSION}

This study showed that cork oak populations have significant levels of phenotypic differentiation as indicated by their morphological traits. Differentiation was evident for growth traits from both univariate and multivariate comparisons based on the matrix distances between provenances and populations. From an analysis of early trials of Mediterranean cork oak provenances, Moroccan ones were found to be better than the remaining material [23]. It is now accepted that the best provenances come from Morocco, especially the Oulmes pile 65. No provenance-block interaction was found in this study, which includes multi-locality provenances and a wide geographical range. It suggests absence of local effects on the specific adaptability of provenances. The evolutionary history of a region determines the distribution of the genetic variability within and among populations of a given species $[2,9,33]$. In other plant, important clinal effects have been found e.g. Pinus sylvestris $[16,30,31]$. In our case, we suggest that differences among populations can be related to the climate of the seedling sources [10], since correlation between phenotypic traits and characteristics of origin sites was significant. Although it is relatively easy to demonstrate that inter-populations and interspecific variation for quantitative traits is different from zero [7], this is not the appropriate null hypothesis for detecting the action of natural selection in leading to population differentiation $[18,19,22]$. Indeed it has been proven difficult to demonstrate that variation among species exceeds the minimum rate of neutral phenotypic evolution [20]. Comparison of $Q_{s t}$ and $G_{s t}$ can provide insight on the relative importance of natural selection and random genetic drift in population differentiation. In theory, the value of $Q_{s t}$ for a selectively neu- tral trait should be the same as that of $G_{s t}$. That is, if $Q_{s t}$ is significantly different from $G_{s t}$, the null hypothesis of the trait arising by genetic drift alone can be rejected [26, 38]. In cork oak, $17.8 \%$ of the total genetic variation measured over the growth traits is attributable to differentiation among populations. This value was higher than Toumi and Lumaret (1998) value (11\%) and was relatively higher than the mean value (7\%) obtained over 25 oaks species studied for enzyme polymorphism [17], this suggests that natural selection has favoured different phenotypes in different populations. Indeed, Merilä and Crnokrak (2001) reviewed results from several taxa for which estimates of both $G_{s t}$ and $Q_{s t}$ were available, and found that $G_{s t}$ exceeded rarely $Q_{s t}$, suggesting that natural selection is a widespread source of differentiation between populations. There are at least two alternative explanations for this pattern of variation: (i) populations of Quercus suber have become differentiated as a result of an heterogeneous (and nonclinal) regime of selection, which has led each population to its local optima; and/or (ii) differentiation is a consequence of genetic drift produced by the lack of gene flow between populations, and by founder events. It could be expected for geographically adjacent populations to have similar environmental conditions and, possibly, similar abiotic selective pressures [6]. Such a selective hypothesis would predict a tendency of closer populations to share similar morphologies. Thus, we would expect a negative relationship between growth similarity among provenances and the distance separating their origin. In contrast, the genetic drift hypothesis does not predict any relationship. This analysis (Fig. 1) supports the selective hypothesis: provenances from each region tend to be clumped.

The UPGMA and $Q_{s t}$ results suggest that selection affected the discrete traits in such a way that unifying selection has 
acted within the geographic groups but this unifying selection has differed between the geographic groups. This diversity among populations in morphological characters, as generally reported for many forest tree species, may result from typical out crossing reproductive system and the intense gene flows between species, this was shown particularly between Holm oak and cork oak $[5,41]$. It has been, also, well established that survival and regeneration in cork oak is deeply affected by predation, particularly by Sus scrofa. Indeed, the biotic effect has been implicated as a factor responsible for cork oak regeneration loss [12] since the intensity of these different types of predation can vary spatially and temporally among populations. This source of regression in regeneration of cork oak can act as a potent source of diversifying selection among Quercus suber populations.

In conclusion, according to the relative high genetic polymorphism of this species in comparison with others oaks species [39], this study allowed us to distinguish between provenances and to validate the morphometrical approach as a tool for early selection of provenances for afforestation. In addition, this work provides useful information about Quercus suber spp. variability, either in this project or in future ecological and genetic investigations.

\section{REFERENCES}

[1] Alia R., Gil L., Pardos J.A., performance of 43 Pinus pinaster Ait. Provenance on 5 locations in centrale Spain, Silvae Genet. 44 (1995) 75-81.

[2] Avise J.C., Phylogeography, the history and formation of species, Harvard University Press, Cambrige, Massachusetts, 2000.

[3] Burollet P., Remarques géodynamiques sur le nord-est tunisien, C.K. Somm. SOC Geol. Fr., 8 (1971) 411-414.

[4] Burollet R., Byramjee R.S., Réflexion sur la technique globale. Exemples africains et méditerranéens, Comp. franç. des pétroles, Notes et mémoires, 1974, pp. 71-120.

[5] Elena-Rossello J.A., Lumaret R., Cabrera, E. Michaud H., Evidence for hybridization between sympatric Holm oak and cork oak in Spain based on diagnostic enzyme markers, Vegetatio 99-100 (1992) 115-118.

[6] Endler J., Geographic variation, Speciation, and clines, Princeton University Press, Princeton, NJ, 1977.

[7] Endler J.A., Natural selection in the wild, Princeton University Press, Princeton, NJ 1986.

[8] Eriksson G., conservation of noble hardwoods in Europe, Can. J. For. Res. 31 (2001) 577-587.

[9] Faith D.P., Conservation, evaluation and phylogenetic diversity, Biol. Conserv. 61 (1992) 1-10.

[10] Frison E., Varela M.C., Turok J. (Eds.), Quercus suber network, Report of the first two meetings 1-3 December 1994 and 26-27 February 1995, Rome, Italy, 1995.

[11] Guttman S.I., Weigt L.A., Electrophoretic evidence of relationships among Quercus (oaks) of eastern North America, Can. J. Bot. 67 (1988) 339-351.

[12] Hasnaoui B., Régénération naturelle du chêne liège : difficultés et propositions de solutions, Ann. l'ENRGREF, Numéro spécial, 1998.
[13] Hokanson S.C., Isebrands J.G., Jensen R.J., Hancock J.F., Isozyme variation in oaks of the Apostle islands in Wisconsin: genetic structure and levels of inbreeding in Quercus rubra and Q. ellipsoidalis (Fagaceae), 1993.

[14] Jensen R.J., De Piero R., Smith B.K., Vegetative characters, population variation and the hybrid origin of Quercus ellipsoidalis, Am. Midl. Nat. 111 (1984) 364-370.

[15] Jensen R.J., Assessing patterns of morphological variation of Quercus spp. in mixed-oak communities, Am. Midl. Nat. 120 (1988) 120-135.

[16] Junttila O., Effects of temperature on shoot growth in northern provenances of Pinus sylvestris L, Tree Physiol. 1 (1986) 185-192.

[17] Kremer A., Petit R.J., Gene diversity in natural populations of oak species, Ann Sci. For. 50 (1993) 186-202.

[18] Lande R., Natural selection and random genetic drift in phenotypic evolution, Evolution 30 (1976) 314-334.

[19] Lande R., Stastistical tests for natural selection on quantitative characters, Evolution 31 (1977) 442-444.

[20] Lynch M., The rate of morphological evolution in mammals from the standpoint of the neutral expectation, Am. Nat. 136 (1990) 727741.

[21] Lynch M., A quantitative genetic perspective on conservation issues, in: Avise J., Hamrik J. (Eds.), Conservation genetics: case histories from nature Chapman and Hall, New York, 1996, pp. 471501.

[22] Lynch M., Hill W.G., Phenotypic evolution by neutral mutation, Evolution 40 (1986) 915-935.

[23] Lourenço M.J., Almaida M.H., Chambel M.R., Varela M.C., Petit R.J., Pereira J.S., Genetic variation of Quercus suber: a tool for regeneration of cork oak woodlands, http://www.ecologicalrestoriation.net/archivos/lourenco.

[24] Manos P.S., Fairbrothers D.E., Allozyme variation in population of six northeastern American red oaks (Fagaceae: Quercus subgenus Erythrobalanus), Syst. Bot. 12 (1987) 365-373.

[25] Mantel N.A., The detection of disease clustering and a generalized regression approach, Cancer Res. 27 (1967) 209-220.

[26] Mckay J.K., Latta R.G., Adaptive population divergence: markers, QTL and traits, Trends Ecol. Evol. 17 (2002) 285-291.

[27] Merilä J., Crnokrak P., Comparaison of genetic differentiation at marker loci and quantitative traits, J. Evol. Biol. 14 (2001) 892903.

[28] Podolosky R.H., Holtsford T.P., Population structure of morphological traits in clarkia dudleyana. I. Comparaison of Fst between allozymes and morphological traits, Genetics 140 (1995) 733-744.

[29] Rouvier H., Géologie de l'extrême Nord tunisien. Tectoniques et paléogéographie superposées à l'extrémité orientale de la chaîne Nord-magrebine, Thèse doctorat d'état, Univ. Pierre et Marie Curie, 1977.

[30] Rubuy J.L., The correspondence between genetic, morphological and climatic variation patterns in scotch pine, Silvae Genet. 16 (1967) 50-56.

[31] Saatcioglu F., Results of the 25 year's provenance experiment established by using 16 Scotch pine of European and 1 of native provenances in turkey, Silvae Genet. 5 (1967) 172-177.

[32] Samuel R., Pinsker W., Ehrendorfer F., Electrophoretic analysis of genetic variation within and between populations of Quercus cerris, $Q$. pubescens, $Q$. petraea and $Q$. robur (Fagaceae) from eastern Austria, Bot. Acta 108 (1995) 290-299.

[33] Schaal B.A., Haywood D.A., Olsen K.M., Rausher J.T., Smith W.A., Phylogeographic studies in plants: problems and prospects, Mol. Ecol. 7 (1998) 465-474. 
[34] Schanabel A., Hamrik J.L., Comparative analysis of populations genetics structure in Quercus macrocarpa and Q. gambelli (Fagaceae), Syst. Bot. 15 (1990) 240-251.

[35] Snedecor G.W., Cochran W.G., Statistical methods, The Iowa State University Press, Ames, lowa, USA, 1967.

[36] Sokol R.R., Michener C.D., A statistical method for evaluating systematic relationships, Univ. Kansas Science Bulletin 28 (1958) 1409-1438.

[37] Sokal R.R., Rolf F.J., Biometry, San Francisco, W. H. Freeman Co., 1995.

[38] Spitze K., Population structure in daphnia obtuse: quantitative genetics and allozymic variation, Genetics 135 (1993) 367-374.

[39] Soulé M.E., Mills L.S., conservation genetics and conservation biology: a troubled marriage, in: Sandlund O.T., Hindar K., Brown A.H.D. (Eds.), Conservation of biodiversity for Sustainable Development, Scandinavian University press, 1992, pp. 55-69.
[40] Storfer A., Quantitative genetics: a promising approach for the assessment of genetic variation in endangered species, Trends Ecol. Evol. 11 (1996) 343-348.

[41] Toumi L., Lumaret R., Allozyme variation in cork oak (Quercus suber L.): the role of phylogeography and genetic intogression by other Mediterranean oak species and human activities, Theor. Appl. Genet. 97 (1998) 647-656.

[42] Tucker J.M., Hybridization in California oaks, Fremontia 18 (1990) 13-19.

[43] Weir B.S., Cokerham's C.C., Estimating F-statistics for the analysis of population structure, Evolution 38 (1984) 1358-1370.

[44] Young A., Boshier D., Boyle T., Forest Conservation Genetics: Principles and practice, CABI Publishing, Wallingford, UK, 2000.

[45] Zanetto A., Kremer A., Labbe T., Diffrences of genetic variation based on isozymes of primary and secondary metabolism in Quercus petraea, Ann. For. Sci. 50 (1993) 245-252. 